\title{
GUIDELINES FOR QUALITATIVE RESEARCH IN ORGANIZATION STUDIES: CONTROVERSY AND POSSIBILITIES
}

DIRETRIZES PARA PESQUISAS QUALITATIVAS EM ESTUDOS ORGANIZACIONAIS: CONTROVÉRSIAS E POSSIBILIDADES

\author{
Recebido em: 31/01/2017 - Aprovado em: 17/04/2017 \\ Avaliado pelo sistema double blind review \\ Editora Científica: Claudia Stadtlober \\ DOI 10.13058/raep.2017.v18n3.522
}

\section{MARIA FERNANDA RIOS CAVALCANTI maria.cavalcanti@puc-campinas.edu.br}

PONTIFÍCIA UNIVERSIDADE CATÓLICA - CAMPINAS

\begin{abstract}
The aim of the present article is to tackle the controversy of establishing guidelines for qualitative research in Organization and Management Theory (OMT) and to present a summary of suggestions on how to conduct good qualitative research given by methodologists on top-tier international publications. In order to do so, the article discusses: general guidelines for qualitative research; how to achieve coherence and transparency in a qualitative empirical study; the meaning and importance of the concept of reflexivity; and, finally how to establish a theoretical contribution and transferability of findings in such context. The work presents a valuable contribution because such guidelines, concepts, and approaches can be adopted by students and researchers when conducting a qualitative research proposal, and by periodic reviewers to evaluate the quality of existing empirical studies.
\end{abstract}

Keywords: Research. Methodology. Qualitative Methods. Criteria for Evaluation.

\section{RESUMO}

O objetivo do presente artigo foi abordar a controvérsia sobre o estabelecimento de diretrizes para a pesquisa qualitativa em estudos organizacionais e apresentar um resumo de sugestões sobre como realizar uma boa pesquisa qualitativa dadas por metodólogos em publicações internacionais de primeira linha. Para tanto, $o$ artigo discute: diretrizes gerais à pesquisa qualitativa; como alcançar coerência e transparência em um estudo empírico qualitativo; o significado e a importância do conceito de reflexividade; e, finalmente, como estabelecer uma contribuição teórica e transferência de resultados em tal contexto. O trabalho propiciou valiosa contribuição porque tais diretrizes, conceitos e abordagens podem ser adotados por estudantes e pesquisadores ao realizarem e conduzirem uma proposta de pesquisa qualitativa, bem como por revisores de periódicos para avaliar a qualidade dos estudos empíricos existentes.

Palavras-Chave: Pesquisa. Metodologia. Metodologia Qualitativa. Diretrizes Metodológicas. 


\section{INTRODUCTION}

The aim of the present article is to tackle the controversy of establishing standards for qualitative research in Organization and Management Theory and to present a summary of suggestions on how to conduct good qualitative research as given by top methodologists in the field. These suggestions may be adopted by students, researchers, and even by reviewers while constructing a proposal to conduct qualitative research and/or evaluating/ assessing the quality of an existent empirical research. As pointed out by Wolcott (2001), the issue of research methods is complex and cannot be limited to discussing techniques of gathering data: methodology refers to the underlying principles of inquiry, which guides the research process. This fact substantially increases the difficulties present in the task of designing and evaluating the adequacy and overall quality of research methods and the communication of their findings. Qualitative research, in particular, imposes a greater difficulty in such matters, which justifies the relevance of the present paper.

In fact, recent literature on OMT has been increasingly raising the issue of the necessity of establishing standards for qualitative research, which inevitably takes us to a basic dilemma of qualitative methods and its quest for legitimacy within the institutional atmosphere, notably that of OMT, which has historically favored quantitative studies (ATKINSON, 2004; FRESHWATER et al., 2010). Although the favoring of quantitative studies in OMT cannot be denied, the author of this paper particularly agrees with the position held by Wolcott (2001) who asserts that pitting qualitative and quantitative methods in opposition does a great disservice to both approaches, for it detracts from the contribution to be made by both. Besides, we are witnessing a considerable change in that historical trend, with important barriers to the publication of qualitative research in this field being broken in the last 30 years (MILES, 1979; SUTTON, 1997; WHITTEMORE; CHASE; MANDLE, 2001; CUNLIFFE, 2011; BAILEY, 2014; SINGH, 2015). A recent example of the growing recognition of qualitative research can be found in the Academy of Management Journal, 
which garnered $30 \%$ of its best paper awards to qualitative studies articles (even though they represent only $7 \%$ of the total papers published by this journal)(LOCKE, 2011).

A possible reason for the historical uneven embracing of quantitative and qualitative studies may be simply because the second is less known. This is so because, as highlighted by Goertz and Mahoney (2012), quantitative methods tend to be more explicit and systematic, whereas qualitative studies tend to be more implicit regarding their assumptions and standard practices. This tendency is especially troublesome for qualitative studies, since such studies contain an overwhelming plethora of different terminologies and positions that may be adopted in different studies (whether they are ontological, epistemological or methodological) (KREFTING, 1991; BALLINGER, 2004; GUBA and LINCOLN, 2004; MEYRICK, 2006; EASTERBY-SMITH; GOLDEN-BIDDLE; LOCKE, 2008; KUPER; LINGARD; LEVINSON, 2008; PRATT, 2008; GOERTZ and MAHONEY, 2012). In fact, such multiplicity makes it even difficult to define what qualitative research actually is. A couple of decades ago, Van Maanen (1979) went as far as to affirm that there's no precise meaning for the term qualitative methodology. Instead, according to the author, it can be considered an "umbrella term covering an array of interpretive techniques which seek to describe, decode, translate, and otherwise come to terms with the meaning, not the frequency, of certain more or less naturally occurring phenomena in the social world" (VAN MAANEN, 1979: p. 520).

The inner diversity of qualitative studies combined with the fact that they tend to be implicit regarding their assumptions and methodological choices is troublesome. It is so because it makes it difficult to identify and build guidelines for conducting such studies, raising the bar especially for novices in the field of OMT to get their research published (RUBIN, 2000; GIBBERT and RUIGROK, 2010; GARSIDE, 2013). While reliability, validity, and generalization provide the basic, and well agreed upon, framework for evaluating quantitative research (MAYS and POPE, 1995), they may not be applied to the evaluation of qualitative research (SEALE, 1999). The lack of agreement of what constitutes good qualitative research, therefore, is 
potentially harming to those interested in conducting and publishing qualitative studies, for it even makes it difficult to review such works, possibly diminishing their acceptance and the impact of their findings (GARSIDE, 2013).

Still, one well agreed upon aspect of qualitative studies is the attractiveness of their data, which justifies the risk of entering such venture. According to Miles (1979), organizational researchers were drawn to qualitative data because it is perceived to be "rich, full, earthy, holistic, 'real'; their face validity seems unimpeachable; they preserve chronological flow where that is important, and suffer minimally from retrospective distortion" (p. 590). For decades, however, the inner difficulties of designing and evaluating qualitative research have diminished this potential. As explained by Miles (1979), the lack of explicitness, data overload, the time required for write-up, coding, and analysis have taken their token out of qualitative researchers. The author also adds that "the most serious and central difficulty in the use of qualitative data is that methods of analysis are not well formulated $[\ldots]$ the analyst faced with a bank of qualitative data and has very few guidelines" (p. 590).

Although discussing and establishing guidelines, criteria and/or standards for designing and evaluating qualitative research is the object controversy among researchers (TRACY, 2013), this does not invalidate the discussion proposed by this paper. I argue that because it is well agreed upon, in one hand, that qualitative studies have great potential to contribute to the field of OMT and, on the other hand, that there are various sources of difficulties in doing and writing qualitative research, these two points alone call for researchers to discuss possible solutions for dealing with the inner difficulties of this type of research. Such solutions, I believe, include bringing the matter of criteria and the need to establish some sort of explicit guideline for authors and reviewers to light. This article, therefore, aims at making a contribution towards this direction. 


\section{TO STABLISH OR NOT TO STABLISH STANDARDS FOR DESIGNING AND EVALUATING QUALITATIVE RESEARCH?}

As put by Tracy (2013), the main source of controversy in the discussion regarding the establishment of standards or criteria for evaluating the rigor and overall quality of qualitative research is the fact that such criteria are constructed and not given. Because of this, authors such as Bochner (2000) argue that trying to establish such criteria is highly problematic and even senseless. Yet, I argue that even though such criteria cannot be taken for granted, and even though they are precarious and mutable establishments, they should be object of discussion if qualitative researchers want to improve their chances of getting published and enhancing the impact of their findings. Besides, explicitly tackling the issue of what makes good qualitative studies is primordial for reviewers and especially relevant for novices in the field of OMT.

The point brought up that the criteria for evaluating qualitative research are constructed coincides with the main line of argument made by Goertz and Mahoney (2012) who affirm that qualitative research has its own tradition, in other words, its own values, beliefs, and norms, thus constituting a culture that shapes its procedures, practices and what is considered valid and trustworthy knowledge among members of the scientific community. This being said, it is important to let readers beware, beforehand, that this so called culture, these agreements among scholars on what constitutes good qualitative research, are not consensual or immutable, but historical and thus temporary phenomena (SPARKES, 2001).

In a well-known discussion among influential contemporary philosophers of science such as Feyerabend (2010) and Chalmers (1999) this historicity of the methods of scientific inquiry has been widely recognized. This also includes the highly successful, widespread, and considerably stable positivistic methods in natural sciences, for example. Therefore, when it comes down to social sciences and qualitative methods in specific, the mutable aspect of methods becomes considerably more recognizable, given the more precarious levels of explicit agreement among researchers 
regarding methodological standards. This, however, cannot be translated into pure relativism, or the logics of "anything goes": quite the opposite, I argue that it should be seen as a window of opportunity to reflect on our methods and to constantly improve them. As it was similarly put by Chalmers (1999), "if we have a conception of science as an open-ended quest to improve our knowledge, then why cannot there be room for us to improve our methods and adapt and refine our standards in the light of what we learn" (p. 162). This "window of opportunity", therefore, is wide open for qualitative methods in special, precisely because its standards have not been so well defined when compared to quantitative/positivistic methods, for example.

Notwithstanding, although qualitative research lack well agreed upon standards regarding its methods, this topic has been recently discussed in social sciences in general and in OMT in particular. These works are assisting academics in the quest to understand the otherwise implicit nature of the qualitative research culture. As asserted by Savall et al. (2008), it is important to reflect on such criteria even when they present themselves in the form of "intangible cues" most of the times. Therefore, on the next topic I will present a summary of the main explicit guidelines and/or intangible cues given by top methodologists in the field of OMT regarding what they believe are the characteristics of good qualitative research. 
GENERAL GUIDELINES FOR CONDUCTING QUALITATIVE STUDIES IN OMT

Even though there has been recent discussion surrounding qualitative methods and its standards, the absence of well agreed upon guidelines for conducting qualitative research described by Miles (1979) seems to have persisted over time. Conflicting views among scholars regarding the fruitfulness of establishing so called criteria to evaluate qualitative research still persist as it was argued in the previous topic. Before exploring what methodologists are saying about what constitutes good qualitative research, it is important to acknowledge what their critics argue. Bochner (2000), for example, argues that the demand for establishing such criteria may restrict freedom and creativity, thus possibly subtracting from qualitative data what made it attractive in the first place. Others disagree, like Whittemore, Chase, and Mandle (2001), who argue that the creativity and richness of qualitative data should be preserved, but not at the expense of analytically rigorous and explicit methodological procedures.

Nonetheless, several authors have presented characteristics that qualitative studies should seek to accomplish, as Table 1 summarizes: 
Table 1 Desired Characteristics for Qualitative Research

\begin{tabular}{|c|c|}
\hline Author(s) & CHARACTERISTICS \\
\hline Ballinger (2004) & Reflexive; transparent; useful \\
\hline Bansal and Corley (2012) & $\begin{array}{l}\text { Engaging; personal; transparent; situates } \\
\text { data in a unique context; narrates skillfully; } \\
\text { revelatory }\end{array}$ \\
\hline Cunliffe (2011) & Authentic; plausible; elegant \\
\hline $\begin{array}{l}\text { Easterby-Smith; } \\
\text { Golden-Biddle and } \\
\text { Locke (2008) }\end{array}$ & $\begin{array}{c}\text { Theoretically informed; systematic; has } \\
\text { well-supported research claims; revelatory; } \\
\text { reflexive }\end{array}$ \\
\hline Finlay (2006) & $\begin{array}{l}\text { Coherent and clearly described; credible; } \\
\text { revelatory; engaging; caring }\end{array}$ \\
\hline $\begin{array}{l}\text { Golden-Biddle } \\
\text { and Locke (1993) }\end{array}$ & Authentic; plausible; critical \\
\hline $\begin{array}{l}\text { Kuper, Lingard, and } \\
\text { Levinson (2008) }\end{array}$ & Reflexive; transparent; transferable; ethical \\
\hline Meyrick (2006) & Transparent; systematic \\
\hline Pratt (2008) & $\begin{array}{l}\text { Firmly embedded in existing theory and } \\
\text { contributes to it; provides enough data and } \\
\text { interpretation; detailed; transparent }\end{array}$ \\
\hline Savall et al. (2008) & $\begin{array}{l}\text { Rigorous; readable; coherent; original; } \\
\text { relevant; traceable/sufficiently explained; } \\
\text { anchored/contextualized; reasonable } \\
\text { findings; dense and concise }\end{array}$ \\
\hline $\operatorname{Tracy}(2010)$ & $\begin{array}{l}\text { Worthy topic; rich rigor; sincerity; credibility; } \\
\text { resonance; significant contribution; ethics; } \\
\text { meaningful coherence. }\end{array}$ \\
\hline $\begin{array}{l}\text { Trainor and Graue } \\
\qquad(2014)\end{array}$ & Embedded in theory; transparent; reflexive \\
\hline
\end{tabular}


As it was put in the last topic, any agreement on desired characteristics of qualitative studies are open and mutable. However, it can be asserted from the above readings that there is a fair amount of consensus among scholars who discussed the topic regarding the desired characteristics of "good" qualitative research. This makes it clear that there is a common ground or a so called "culture" among qualitative researchers (as it was argued by GOERTZ; MAHONEY, 2012). As Table 1 shows, the main points of agreement among these scholars were that qualitative research should, preferably:

a. Be coherent, systematic/traceable and transparent regarding its methodological choices and procedures;

b. Be skillfully and creatively written;

c. Provide well supported and revelatory/relevant explanations;

d. Be reflexive and ethical;

e. Have a clear theoretical background and contribute to theory.

Thus, to put it in few words, what the above points ultimately demonstrate is the dilemma of qualitative research, which basically consists of trying to become, at the same time, creative and systematic, imaginative and real, insightful and theoretically grounded, transparent (thus reflexive and humble) and scientific, highly contextualized and generalizable. This task certainly is not an easy one, therefore the need to have some sort of guideline for achieving such characteristics is an urgent and relevant matter.

May I observe, firstly, that point (b) is certainly the most difficult one to be explored for its high degree of uncertainty, after all: is there any sort of recipe for skillful and creative writing? I believe that the truth is we, as organizational researchers, are talking much less about our own creative processes and writing techniques than we should be. This is particular troublesome for novices and, may I add, it is a powerful source of traumatic experiences for many Master's degree and PhD students - who many of us have, sadly, surely witnessed. The issue of writing would make a great topic 
for another article and maybe, who knows, an empirical study? Let us leave this invitation open. As for points (a), (c), (d), and (e) a considerable amount of influential authors in OMT have shared their thoughts and beliefs on how to tackle them. They will be presented in the following topics. 
COHERENCE AND TRANSPARENCY IN QUALITATIVE RESEARCH: ESTABLISHING SYSTEMATIC RESEARCH FROM DIFFERENT METATHEORETICAL POSITIONS

The existence and development of different metatheoretical positions explains in part the complexity of qualitative research, and considering them is essential for those interested in building persuasive, consistent and credible accounts. The first point to be made here is that, as affirmed by Amis and Silk (2007), the coherence and transparency of qualitative research can only be discussed and considered once there is a clear establishment of the researcher's ontological, epistemological, political and axiological orientations. Without this positioning, the researcher faces the great danger of falling into relativism, or anything goes logic, where methodological choices are obscured and/or unjustified. This is a crucial step in designing qualitative research, since the existence of obscure and/or unjustified methodological choices are still perceived as being a weakness in a substantial part of qualitative studies (ONWUEGBUZIE and LEECH, 2005). In fact, as pointed out by Hammerseley (1992), judgments of the adequacy of the results and knowledge claims made in one's research can only be made once one has revealed the metatheoretical positions or assumptions that guided the inquiry process. In other words, a solid qualitative research design must be closely tied to a theoretical framework that drives inquiry and thus explicitly justifies a study's methodological choices (OLIVER, 2011).

Therefore, in order to guarantee methodological coherence, it is suggested that the researcher first clearly presents her/ his theoretical assumptions. This assertion is based on the premise that any research, or any attempt to understand the world and its phenomena in a systematic manner, starts from an assumption on the nature of reality. Some authors call this positioning ontology, while others prefer to call it problematic. Building on the previous discussions around the nature of qualitative studies, it can be said that the main common ground regarding their ontological assumption is that reality is not purely objective. Therefore, in the context of qualitative studies, the aim of an ontological elucidation is to account for both the 
nature of the individuals involved in a research (subjectivity, action, agency, knowledge, etc.) and the nature of social phenomenon under investigation. In other words, ontology accounts for the nature of who knows and the nature of what can be known. In such context, therefore, epistemology is closely tied to ontology, but it refers more specifically to the latter or, in other words, to what can be known and, also, to how a given reality can be known (GRECO, 1999). Thus, since the production of knowledge lies in the heart of any scientific inquiry (may it be qualitative or otherwise), ontology and epistemology cannot be separated in this realm.

For example, a study that wishes to investigate daily practices in a given organization, as such practices unfold, even though this is a quite general initial orientation, it already contains a series of philosophical assumptions. The fact that in its initial stages such research may only hold very general orientations is common to many inductive qualitative studies (i.e. to investigate and observe certain organizational practices as they unfold). However, such a general inductive orientation still demands further ontological refinement and a more precise epistemological positioning. As explained by Cunliffe (2015), three different ontologies or problematics have been used to investigate practices in a similar manner in OMT, which are summarized in Table 2 .

The close link between ontology and epistemology in qualitative studies such as practice-based ones can be observed in Table 2. As explained by Cunliffe (2015), these different problematics produce and are produced by different conceptions on the nature and definitions of practice, or three different epistemologies of practice. According to an objectivist view, for example, practices are independent objects or phenomenon abstracted from contexts. Subjectivism views practice as embedded in actions, interactions and conversations of people in a context. An intersubjectivist view, finally, regards practice (including the research practice) as interwoven in relationships between people.

These multiple ways to approach organizational phenomenon such as organizational practices while conducting a qualitative study makes it clear that: (a) first, one needs to refine what one understands of "practices" 


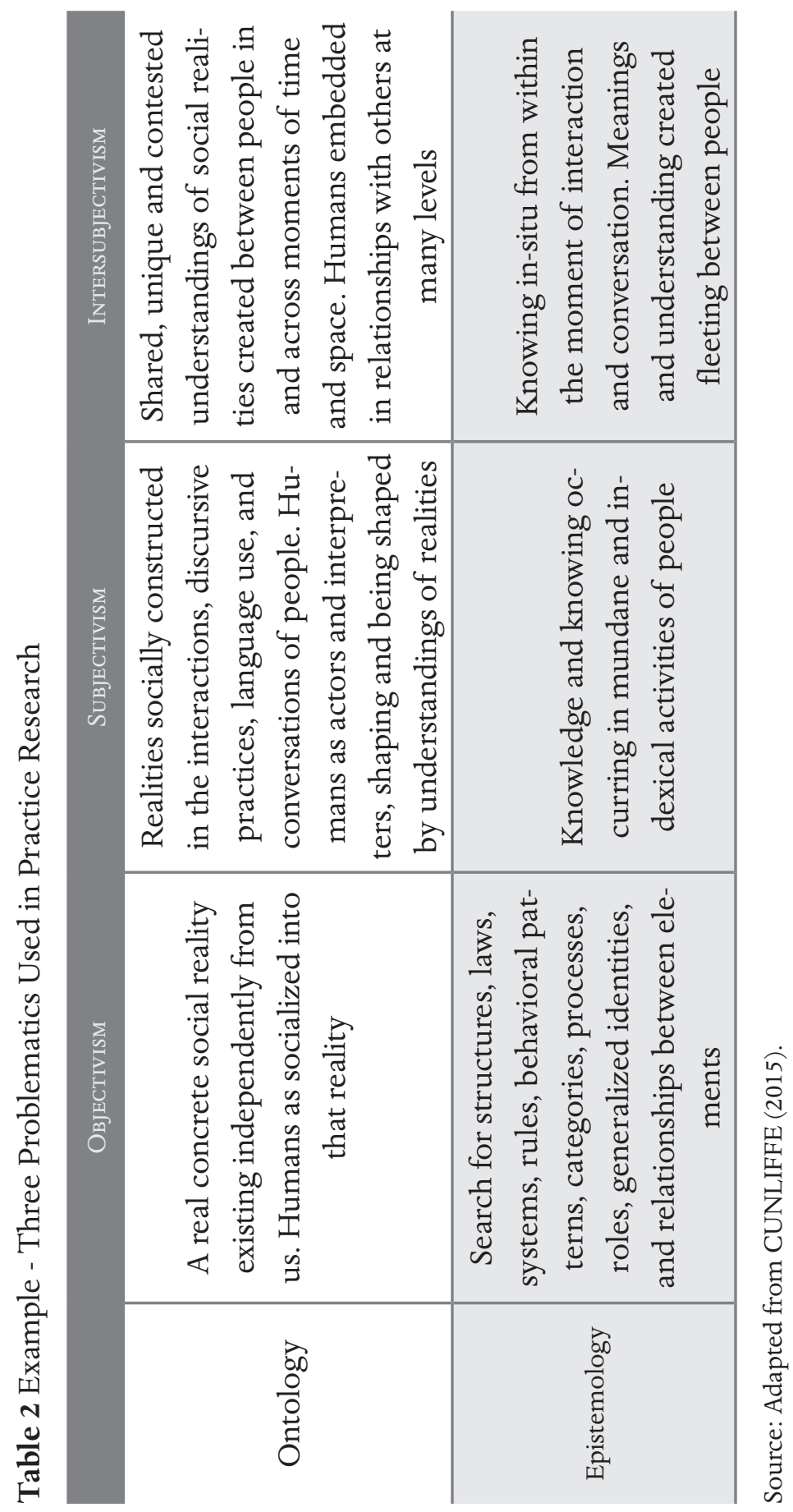


and its assumptions; (b) and, second, this is needed because such assumptions will serve as the guiding points to refine and to present a coherent and transparent research strategy and design. This is also the case when one is investigating organizational phenomenon through lenses other than organizational practices (e.g. discourses, emotions, etc.).

Although qualitative studies may have varied metatheoretical assumptions and/or positions they also share common grounds from which general guidelines may be derived, as previously argued. Besides, qualitative research raises concerns that extrapolates the pure objetivist/positivistic views of science, as for example, the issue of the researchers' reflexivity. As reflexivity was mentioned by a considerable number of authors as something that should be looked at when one is assessing the quality of these studies, in the next topic we will examine the meaning of reflexivity and its importance for qualitative research in general. 


\section{REFLEXIVITY AND ETHICS IN QUALITATIVE RESEARCH}

Reflexivity was first brought into methodological discussions in the early 1970 's, as a reaction to classical approaches to sociological research that have since sometimes been labeled as an expression of a "colonial" anthropology (Wasserfall, 1997). This theme first emerged in the works of feminist ethnographers who questioned the power and privilege of researchers and claimed for a greater equality among academics and research participants (Alkon, 2011). Since then, reflexivity has outgrown ethnography and has been recognized as an important trait of qualitative research in general (Macbeth, 2001; Pillow, 2003; Rhodes, 2009; Bott, 2010; Berger, 2015). Furthermore, it has been considered an element that permeates every aspect of its process (Hertz, 1997). The essential critique brought up by the reflexivity discussion is the acknowledgement that doing research is about saying something about and representing an "Other", which implicates the development of unequal relationships between researchers and participants.

Reflexivity becomes an important tool for reflecting upon the appropriateness of one's methodological choices, especially because of the general orientation present in most qualitative studies, which proposes that researchers must immerse themselves into the reality under study. Therefore, in many qualitative studies, the researcher must become "one of them" among the research participants. The necessity to "become one of them" implies recognizing two points: firstly, of course, that I, as a researcher, am not one of them; and, secondly, that the researcher must reflect on what it means to become one of them and if that is in fact possible - even in ethnographic studies, which require extreme immersion in the field.

As pointed out by Cunliffe (2003), by bringing the relationship between researchers and participants to the foreground, reflexivity has the role of "unsettling" representation and its claim of objective truth, one of the counter stones of qualitative inquiry. Alvesson, Hardy, and Harley (2008) assert that reflexive research cannot support claims of objective truth since it turns back upon itself and reveals the socio-political positions held by 
researchers and research participants and shows how they affect the research process (see also Ballinger, 2004; Cunliffe, 2003). Therefore, it must be pointed out that reflexivity is subjective in its core, and is thus absent from studies that adopt objectivist problematics - even though qualitative studies may also come from this problematic. The unsettlement of the researcher's power to establish objective truths reveals an ethical concern that is present in the notion of reflexivity, as "an implicit part of ethical practice thus involves the acknowledgment and location of the researcher within the research process" (Davies and Dodd, 2002). Another important ethical trait of reflexivity discussions has to do with its concern for separating the researcher's voice from the participant's voice, making it clear that the latter is necessarily filtered and shaped by the first, as the researcher chooses which stories to tell and which stories are to be ignored (Hertz, 1997).

Within the subjectivist and intersubjectivist problematics, reflexivity has thus become an essential part of the qualitative research process. Explicitly monitoring how the researcher-self directly affected the research process and its outcomes within such problematics is supposed to provide qualitative research more reliability (Seale, 1999), plausibility (Buckner, 2005), and validity (Pillow, 2003). Berger (2015) summarizes some examples of how the researcher's reflexivity may affect the research process and its outcomes: (1) it may affect the easiness of access to the field; (2) it may shape the relationship between researcher and researched, this fact directly affecting the information participants are willing to share; (3) worldviews and backgrounds of the researcher directly affect all of her/his choices (from the questions that are asked to how she/he uses language, how she/ he selects data and her/his general meaning making processes) (see also Hertz, 1997).

Bott (2010) argues that the acknowledgement of the researcher reflexivity begins with the researcher constantly locating and relocating herself/himself within her/his work in a constant dialogue that does not leave space for claims of objective knowledge, and which accounts for the subjectivity of the research process. In order to operationalize this constant locating and relocating process in this research I accepted the sugges- 
tion given by Cunliffe and Karunanayake (2013) of using the notion of hyphen-spaces as a way of recognizing and understanding these different positions occupied by the researcher and their impact on the research practice. The authors identified four different hyphen-spaces: insider-outsider, sameness-difference, engaged-distant, and politically active-actively neutral (Figure 1).

Figure 1 also represents the fact that the four hyphen-spaces are interconnected and may be experienced simultaneously and/or in an intertwined manner during fieldwork. I can tell from my own experience as a qualitative researcher that during fieldworks that I was able to experience all four hyphen-spaces, especially when conducting studies in different organizations for an extended period of time. This shifting of hyphen-spaces became very clear especially while conducting participant observations.

Nonetheless, although I could experience position shifts, what such shifts ultimately revealed to me was that I was never fully granted the status of insider as a researcher, or the status of "one of them" in its entirety. Still, it cannot be denied that reflexivity brings about a constant awareness of the researcher's positions during fieldwork, and the constant pursuit to scrutinize such positions directly impact and refine both the research strategy and the study's transparency when reporting findings. 
Figure 1 Hyphen-Spaces of Researcher Reflexivity.

\section{Insiderness-Outsiderness}

Is the researcher "native" to the community being studied?

Does the researcher have na ongoing role in the research site?

Do participants perceive the researcher as "one of us"?

\section{Multiple Researcher-Participants Identities}

Does the researcher engage in activities with participants?

How much is the researcher emotionally involved?

How do participants actively create knowledge in the research?

\section{Engagement-Distance}

\section{Engagement-Distance}

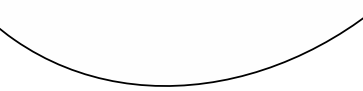

Is the researcher involved in the agendas of participants?

Does the researcher interneve in the struggles of participants?

Is the researcher oriented towards social, organizational

or political change?

Political-

Activism-Neutrality

Source: Cunliffe and Karunanayake (2013, p. 372). 


\section{THE CONTROVERSY OF GENERALIZATION OF FINDINGS IN QUA- LITATIVE RESEARCH}

The generalization of findings in qualitative research has also been the subject of considerable controversy. While some authors discard beforehand such possibility, others prefer to adopt a more mid-term position. Payne and Williams (2005), for example, assert that qualitative research should seek to make. This coincides with the claim made by Mair (2010) regarding theory building made by bottom-up inductive studies in the context of Social Entrepreneurship, which should seek to build mid-range theories, not grand and highly generalizable theories, precisely because research suggests that such type of inductive studies reveal high context sensitivity.

Lincoln and Guba (1985) make a similar claim and, in order to avoid the controversy, propose change in terms asserting that instead of worrying about producing generalizable research accounts, good qualitative research should focus on producing transferable ones. That is, the investigator should focus on providing evidence that will allow readers to make comparisons and possibly transfer some of these findings to other similar contexts if they wish to do so. The authors suggest that the investigator relying on qualitative methods should, then, "provide sufficient descriptive data to make such similarity judgments possible" (LINCOLN and GUBA, 1985, p. 298). However, it is important to highlight that Lincoln and Guba (1985) also argue that in this type of study an investigator cannot fully guarantee generalizability and thus appliers are nevertheless advised to conduct small verifying studies to be certain that the transferability of accounts is indeed plausible.

Moreover, authors like Tracy (2013) prefer the term resonance to refer to a feature of a text that makes it reverberate and impact an audience that perceives it as meaningful across different contexts. The author explains that generalizability should be seen as only one of the several ways to achieve such resonance. The other two ways to achieve resonance proposed by Tracy (2013) are transferability and aesthetic merit, the latter referring to the capacity of a text to emotionally affect its readers. 
Cunliffe (2011) and Golden-Biddle and Locke (1993) affirm that qualitative research must be plausible; Finlay (2006) and Whittemore, Chase and Mandle (2001) use the term credible; Tracy (2010) asserts that it must be meaningfully coherent. Indeed, what such references have in common is the shared belief that qualitative research accounts must be, foremost, perceived as meaningful by their intended audience. Therefore, discussing validity in qualitative studies is not to claim for objective truth, rather, it reflects a concern with producing plausible, credible, or meaningfully coherent research accounts to an intended audience.

Several authors have discussed criteria to analyze the credibility or plausibility of qualitative research accounts, the most cited approaches to tackling these issues are summarized in Table 3.

Table 3 Approaches for Facilitating Transferability of Account

PHASES OF THE

Research Process

\section{ApProACHes}

It is typically tightly scoped within the context of an existing theory. Its justification rests on "the abi-

Research Problem lity of qualitative data to offer insight into complex social processes that quantitative data cannot easily reveal" (EISENHARDT; GRAEBNER, 2007, p. 26)

It links research design to clear ontological and epistemological positions (DENZIN, 1996; TRACY, 2010)

Using Self-Reflexivity or delineating the rela-

Research

Design tionships developed during field work (LECOMPTE; GOETZ, 1982; GOLDEN-BIDDLE; LOCKE, 1993; WHITTEMORE; CHASE; MANDLE, 2001; PILLOW, 2003; BANSAL; CORLEY, 2012; BELL, 2013) 


\begin{tabular}{|c|c|}
\hline $\begin{array}{c}\text { Data } \\
\text { Collection }\end{array}$ & $\begin{array}{l}\text { Explicitly justifying sampling criteria and ad- } \\
\text { dressing sampling constraints (EISENHARDT; } \\
\text { GRAEBNER, 2007; CURTIS et al., 2000) } \\
\text { Prolonged engagement and persistent observa- } \\
\text { tion, or being there (LINCOLN; GUBA, 1985; } \\
\text { GOLDEN-BIDDLE; LOCKE, 1993; ONWUE- } \\
\text { GBUZIE; LEECH, 2005) } \\
\text { Collecting and recording as much data as possi- } \\
\text { ble (MAYS; POPE, 1995) from different collec- } \\
\text { tion modes (LINCOLN; GUBA, 1985) } \\
\text { Identifying the types of data collected and exa- } \\
\text { mining the detailed processes of data collection } \\
\text { (GOLDEN-BIDDLE; LOCKE, 1993) } \\
\text { Using various informants (LECOMPTE; GO- } \\
\text { ETZ, 1982) }\end{array}$ \\
\hline $\begin{array}{c}\text { Data } \\
\text { Analysis }\end{array}$ & $\begin{array}{l}\text { Explicating the systematic and iterative movement } \\
\text { between data collection and data analysis (GOL- } \\
\text { DEN-BIDDLE; LOCKE, 1993) } \\
\text { Using CAQDAS to organize data (WHITTEMO- } \\
\text { RE; CHASE; MANDLE, 2001; CARCARY, 2011) }\end{array}$ \\
\hline $\begin{array}{l}\text { Writing } \\
\text { Style }\end{array}$ & $\begin{array}{l}\text { Adopting more orthodox research standards re- } \\
\text { garding text's format and devices (GOLDEN-BID- } \\
\text { DLE; LOCKE, 1993); Rich description of context } \\
\text { (ARMOUR; RIVAUX; BELL, 2009; EISENHARDT, } \\
\text { 1991); Telling a compelling story (BANSAL; COR- } \\
\text { LEY, 2012; EISENHARDT, 1991; DYER; WILKINS, } \\
\text { 1991) }\end{array}$ \\
\hline
\end{tabular}

Using such cues for achieving some degree of generalization (or transferability) for one's empirical findings alone, however, does not "magically" translate into contributions to theory or to theoretical discovery. There is, therefore, one last discussion to be made: how does the final leap 
to theory occurs? Or, in other words, how do qualitative studies contribute to theory or build theory? As we saw in the first topic, where a summary of general guidelines for qualitative research were presented, this was a crucial point made by methodologists regarding the quality of such studies. Although this is also a topic involved in controversy and a high degree of uncertainty, I will attempt to discuss it in the following topic. 


\section{CONTRIBUTION AND THEORETICAL DISCOVERY IN QUALITATI-} VE STUDIES

As stated by Bansal and Corley (2012), and as it has become clear in the present paper, most qualitative researches contribute to theory using induction. This means that most qualitative researchers do not have a previously established hypothesis that will be empirically tested. As it was explained by Hempel (1966), inductive inferences are the act of coming from particular cases to more general conclusions, as it was discussed in the last topic. Therefore, it can be said that qualitative research has the vocation for theory-building rather than theory-testing. However, there is a tendency to believe that such inductive inferences are to be seen as a stage in the scientific inquiry, whereas these inductively inferred general conclusions are to be tested in a final step to guarantee objectivity. This belief has been refuted by qualitative researchers, as I have previously showed, but this is still the object of controversy.

In a seminal article, Eisenhardt (1989) affirms that a final and crucial step to build theory is to compare the found propositions (findings) or concepts to existent literature and ask ourselves: what do these findings contradict and why? According to the author, to consider conflicting theories will increase the trustworthiness of the findings. In a rather dialectical turn, Eisenhardt (1989) claims that this juxtaposition forces researchers to be creative and to come up with frame-breaking arguments, which would be unachievable with data alone, or without a theoretical counterpoint or an antithesis. Authors such as Klag and Langley (2013) call this a "theoretical leap", and highlight the strongly dialectical aspect of it.

However, this inductive process is far from being simple: in other words, going from raw data to theoretical discovery in qualitative studies. Klag and Langley (2013), for example, characterize this dialectical process of discovery as embedded in "four dialectic tensions: between deliberation and serendipity, between engagement and detachment, between knowing and not knowing, and between self-expression and social connection" ( $\mathrm{p}$. 149). 
Authors like Bansal and Corley (2012) and Tracy (2010) refer to this in a more pragmatic way by calling it an "iterative process". Even though qualitative research in general does not offer clear-cut rules or protocols of how theoretical discoveries are to be made (Bryman, 2001), I found it useful to follow the analytical framework proposed by Spencer, Ritchie and O'Connor (2003) to try to visualize this process, since it provides a comprehensive and clear representation of the different levels of analysis of an iterative thematic analysis and the non-linear character of theoretical discovery in qualitative research.

Although this representation of an iterative process of theoretical discovery is far from being universal or immutable, it is useful for it allows us to see the challenging but highly desired trait of the theoretical leap in qualitative studies: its close adherence to the data. This is important especially because the amount of data generated by qualitative studies, and the complexity of the dialectical forces behind the needed conceptual leap to achieve theoretical discovery, may leave researchers dazzled and lost in field of fuzziness. 
Figure 2 Stages and Processes Involved Theoretical Discovery Through Iterative Analysis

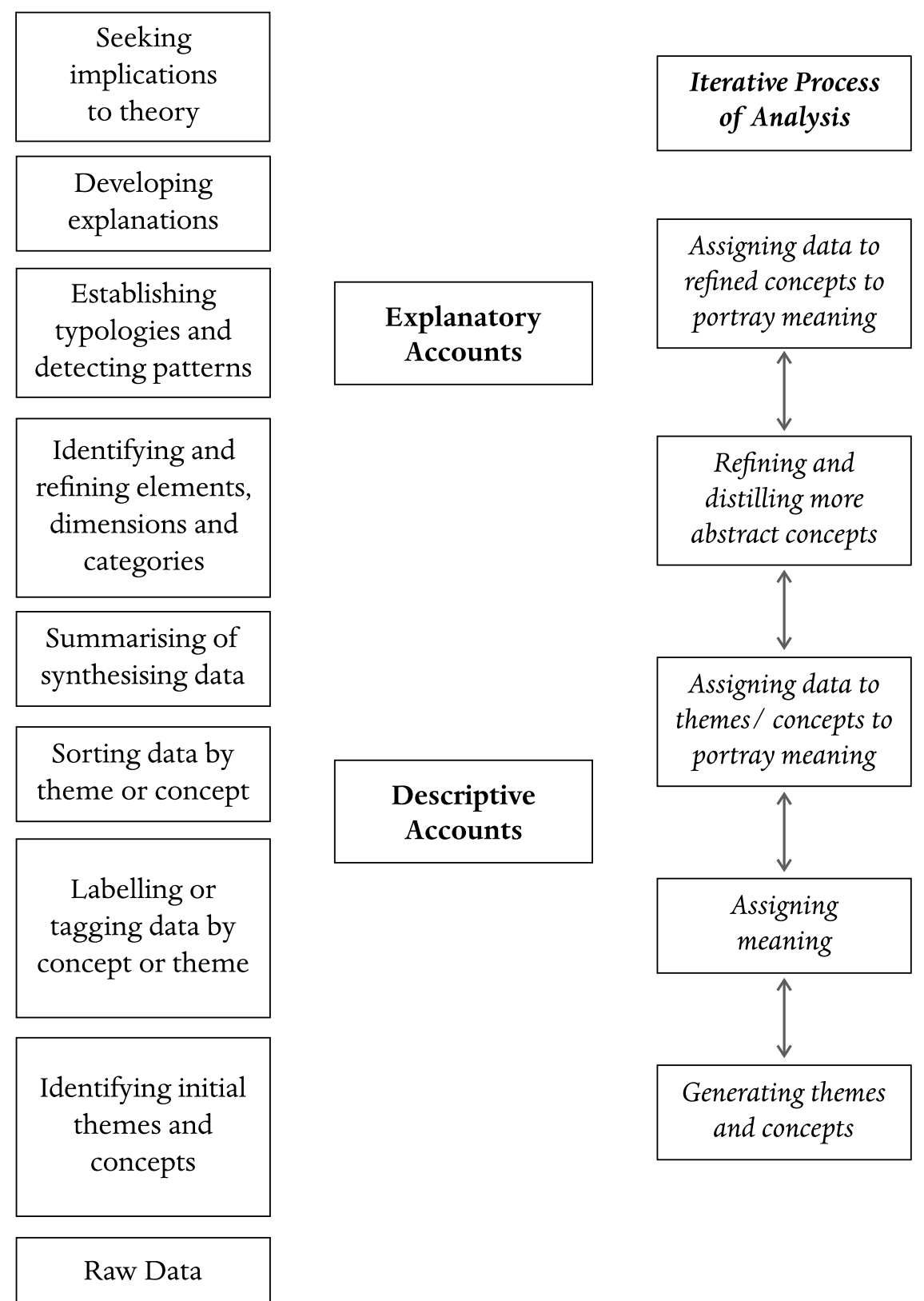

Source: Adapted from Spencer, Ritchie, and O’Connor (2003, p. 212). 


\section{FINAL CONSIDERATIONS}

This paper attempted to tackle to controversy of establishing standards for qualitative research in OMT and to present a summary of suggestions or guidelines given by top methodologists to design and conduct "good" qualitative research. We have seen that, even though this is a controversial topic, it is still a necessary one. Moreover, we have also been able to see that authors agree on a set of common guidelines, and that recent works seem to be pointing at similar directions regarding emergent topics (such as ontological assumptions, reflexivity, the need to present "transferable" findings, and the need for a theoretical leap). Although this discussion is far from being consensual, general guidelines for constructing coherent and transparent qualitative research and for evaluating such works were presented. The paper makes a valuable contribution because the guidelines, concepts and techniques summarized and presented may be adopted by students, researchers and even reviewers, while constructing a proposal to conduct a qualitative research and/or while evaluating/assessing the quality of existent empirical qualitative research. 


\section{REFERENCES}

ALKON, A. H. Reflexivity and Environmental Justice Scholarship: A Role for Feminist Methodologies. Organization \& Environment, v. 24, n. 2, p. 130-149, 2011.

ALVESSON, M.; HARDY, C.; HARLEY, B. Reflecting on Reflexivity: Reflexive Textual Practices in Organization and Management Theory. Journal of Management Studies, v. 45, n. 3 , p. $480-501,2008$.

AMIS, J. M.; SILK, M. L. The Philosophy and Politics of Quality in Qualitative Organizational Research. Organizational Research Methods, v. 11, n. 3, p. 456-480, 2007.

ARMOUR, M.; RIVAUX, S. L.; BELL, H. Using Context to Build Rigor: Application to Two Hermeneutic Phenomenological Studies. Qualitative Social Work, v. 8, n. 1, p. 101-122, 2009.

ATKINSON, E. Thinking outside the box: An exercise in heresy. Qualitative Inquiry, v. 10, p. 111-129, 2004.

BAILEY, L. F. The origin and success of qualitative research. International Journal of Market Research, v. 56, n. 2, p. 167, 2014.

BALLINGER, C. Writing up Rigour: Representing and Evaluating Good Scholarship in Qualitative Research. British Journal of Occupational Therapy, v. 67, n. 12, p. 540-546, 2004.

BANSAL, P.; CORLEY, K. Publishing in AMJ--Part 7: What's Different about Qualitative Research? Academy of Management Journal, v. 55, n. 3, p. 509-513, 2012.

BELL, K. Doing qualitative fieldwork in Cuba: social research in politically sensitive locations. International Journal of Social Research Methodology, v. 16, n. 2, p. 109-124, 2013.

BERGER, R. Now I see it, now I don't: researcher's position and reflexivity in qualitative research. Qualitative Research, v. 15, n. 2, p. 219-234, 2015.

BOCHNER, A. P. Criteria Against Ourselves. Qualitative Inquiry, Communication Faculty Publications, v. 6, n. 2, p. 266-272, 2000.

BOTT, E. Favourites and others: reflexivity and the shaping of subjectivities and data in qualitative research. Qualitative Research, v. 10, n. 2, p. 159-173, 2010.

BRYMAN, A. Social Research Methods. Oxford: Oxford University Press, 2001.

BUCKNER, S. Taking the debate on reflexivity further. Journal of Social Work Practice, v. 19 , p. 59-72, 2005.

BURRELL, G.; MORGAN, G. Sociological Paradigm and Organisational Analysis Elements of the sociology of corporate life. Burlington: Ashgate Publishing, 1979.

CARCARY, M. Evidence Analysis using CAQDAS: Insights from a Qualitative Researcher. The Electronic Journal of Business Research Methods, v. 9, n. 1, p. 10-24, 2011. 
CHALMERS, A. F. What is this Thing Called Science? 3.ed. Indianapolis: Hackett Publishing Company, 1999.

CUNLIFFE, A. Reflexive inquiry in organizational research: Questions and possibilities. Human Relations, v. 56, n. 8, p. 983-1003, 2003.

Crafting Qualitative Research: Morgan and Smircich 30 years on. Organizational Research Methods, v. 14, n. 4, p. 647-673, 2011.

Using ethnography in strategy-as-practice research. In: GOLSORKHI, D.; ROULEAU, L., et al. (Ed.). Cambridge Handbook of Strategy as Practice. Cambridge: Cambridge University Press, 2015. p. 431-446.

CUNLIFFE, A.; KARUNANAYAKE, G. Working Within HyphenSpaces in Ethnographic Research: Implications for Research Identities and Practice. Organizational Research Methods, v. 16, n. 3, p. 364-392, 2013.

CURTIS, S. et al. Approaches to Sampling and Case Selection in Qualitative Research: examples in the geography of health. Social Science \& Medicine, v. 50, p. 1001-1014, 2000.

DAVIES, D.; DODD, J. Qualitative Research and the Question of Rigor. Qualitative Health Research, v. 12, n. 2, p. 279-289, 2002.

DENZIN, N. K. The Epistemological Crisis in the Human Disciplines: Letting the Old Do the Work of the New. In: JESSOR, R. et al. (Ed.). Ethnography and Human Development - Context and Meaning in Human Development. Chicago: University of Chicago Press, 1996. p. 127-152.

DYER, W. G.; WILKINS, A. L. Better Stories, Not Better Constructs, To Generate Better Theory: A Rejoinder to Eisenhardt. Academy of Management Review, v. 16, n. 3, p. 613-619, 1991.

EISENHARDT, K. M. Better Stories and Better Constructs: The Case for Rigor and Comparative Logic. The Academy of Management Review, v. 16, n. 3, p. 620-627, 1991.

EISENHARDT, K. M. Building Theory from Case Study Research. The Academy of Management Review, v. 14, n. 4, p. 532-550, 1989.

EISENHARDT, K. M.; GRAEBNER, M. E. Theory Building from Cases: Opportunities and Challenges. The Academy of Management Journal, v. 50, n. 1, p. 25-32, 2007.

ERDEN, Z.; SCHNEIDER, A.; KROGH, G. V. The Multifaceted Nature of Social Practices: A review of the perspectives on practice-based theory building about organizations. European Management Journal, v. 32, p. 712-722, 2014.

EASTERBY-SMITH, M.; GOLDEN-BIDDLE, K.; LOCKE, K. Working With Pluralism Determining Quality in Qualitative Research. Organizational Research Methods, v. 11, n. 3, p. 419-129, 2008.

FEYERABEND, P. Against Method. 4.ed. New York: Verso, 2010. 
FINLAY, L. 'Rigour', 'Ethical Integrity’ or 'Artistry’? Reflexively Reviewing Criteria to Evaluate Qualitative Research. British Journal of Occupational Therapy, v. 69, n. 7, p. 319-326, 2006.

FRESHWATER, D. et al. Qualitative research as evidence: criteria for rigour and relevance. Journal of Research in Nursing, v. 15, n. 6, p. 497-508, 2010.

GARSIDE, R. Should we appraise the quality of qualitative research reports for systematic reviews, and if so, how? Innovation: The European Journal of Social Science Research, v. 27, n. 1, p. 67-79, 2013.

GIBBERT, M.; RUIGROK, W. The "What" and 'How" of Case Study Rigor: Three Strategies Based on Published Work. Organizational Research Methods, v. 13, n. 4, p. 710-737, 2010.

GOERTZ, G.; MAHONEY, J. A Tale of Two Cultures - Qualitative and Quantitative Research in the Social Sciences. Princeton: Princeton University Press, 2012.

GOLDEN-BIDDLE, K.; LOCKE, K. An Investigation of How Ethnographic Texts Convince. Organization Science, v. 4, n. 4, p. 595-616, 1993.

GRECO, J. Introduction: What is Epistemology? In: GRECO, J.; SOSA, E. (Ed.). The Blackwell Guide to Epistemology. Oxford: Blackwell Publishers, 1999. p.1-32.

GUBA, E. G.; LINCOLN, Y. S. Competing Paradigms in Qualitative Research: Theories and Issues. In: HESSE-BIBER, S.; LEAVY, P. (Ed.). Approaches to Qualitative Research A reader on theory and practice. Oxford: Oxford University Press, 2004. p.17-38.

HAMMERSLEY, M. What's Wrong with Ethnography? London: Routledge, 1992.

HEMPEL, C. G. Philosophy of Natural Science. Upper Saddle River: Prentice Hall, 1966.

HERTZ, R. Introduction. In: HERTZ, R. (Ed.). Reflexivity and Voice. London: SAGE Publications, 1997. p.vii-xviii.

KLAG, M.; LANGLEY, A. Approaching the Conceptual Leap in Qualitative Research International Journal of Management Reviews, v. 15, n. 2, p. 149-166, 2013.

KREFTING, L. Rigor in Qualitative Research: The Assessment of Trustworthiness. The American Journal of Occupational Therapy, v. 45, n. 3, p. 214-222, 1991.

KUPER, A.; LINGARD, L.; LEVINSON, W. Critically appraising qualitative research. British Management Journal, v. 337, p. a1035, 2008.

LECOMPTE, M. D.; GOETZ, J. P. Problems of Reliability and Validity in Ethnographic Research. Review of Educational Research, v. 52, n. 1, p. 31-60, 1982.

LINCOLN, Y. S.; GUBA, E. G. Naturalistic Inquiry. London: SAGE Publications, 1985.

LOCKE, K. Field Research Practice in Management and Organization Studies:

Reclaiming its Tradition of Discovery. Academy of Management Annals, p.613-652, 2011. 
MACBETH, D. On "Reflexivity” in Qualitative Research: Two Readings, and a Third. Qualitative Inquiry, v. 7, n. 1, p. 35-68, 2001.

MAYS, N.; POPE, C. Rigour and Qualitative Research. British Management Journal, v. 31, n. 8, p. 109-112, 1995.

MAIR, J. Social Entrepreneurship: taking stock and looking ahead. In: FAYOLLE, A.; MATLAY, H. (Eds.), Handbook of Research on Social Entrepreneurship. Glos: Edward Elgar Publishing, 2010. p. 15-28

MEYRICK, J. What is good qualitative research? A first step towards a comprehensive approach to judging rigour/quality. Journal of Health Psychology, v. 11, n. 5, p. 799808, Sep 2006.

MILES, M. B. Qualitative Data as an Attractive Nuisance: The Problem of Analysis. Administrative Science Quaterly, v. 24, n. 4, p. 590-601, 1979.

OLIVER, D. P. Rigor in Qualitative Research Editorial. Research on Aging, v. 33, n. 4, p. 359-360, 2011.

ONWUEGBUZIE, A. J.; LEECH, N. L. On Becoming a Pragmatic Researcher: The Importance of Combining Quantitative and Qualitative Research Methodologies. International Journal of Social Research Methodology, v. 8, n. 5, p. 375-387, 2005.

PAYNE, G.; WILLIAMS, M. Generalization in Qualitative Research. Sociology, v. 39, n. 2 p. 295-314, 2005.

PILLOW, W. S. Confession, catharsis, or cure? Rethinking the uses of reflexivity as methodological power in qualitative research. Qualitative Studies in Education, v. 16, n. 2, 2003.

PRATT, M. G. Fitting Oval Pegs Into Round Holes: Tensions in Evaluating and Publishing Qualitative Research in Top-Tier North American Journals. Organizational Research Methods, v. 11, n. 3, p. 481-509, 2008.

RHODES, C. After Reflexivity: Ethics, Freedom and the Writing of Organization Studies. Organization Studies, v. 30, n. 6, p. 653-672, 2009.

RUBIN, A. Standards for Rigor in Qualitative Inquiry. Research on Social Work Practice, v. 10, n. 2, p. 173-178, 2000.

SAVALL, H. et al. The Emergence of Implicit Criteria Actually Used by Reviewers of Qualitative Research Articles. Organizational Research Methods, v. 11, n. 3, p. 510-540, 2008.

SEALE, C. The Quality of Qualitative Research. London: SAGE Publications, 1999.

SINGH, K. D. Creating Your Own Qualitative Research Approach. Vision, v. 9, n. 2, p. 132-146, 2015.

SPARKES, A. C. Myth 94: Qualitative Health Researchers will Agree About Validity.

Qualitative Health Research, v. 11, n. 4, p. 538-552, 2001. 
SPENCER, L.; RITCHIE, J.; O’CONNOR, W. Analysis: Practices, Principles and Processes. In: RITCHIE, J.; LEWIS, J. (Eds.) Qualitative Research Practice - a guide for social science students and researchers. London: SAGE Publications, 2003. p. 199-218.

SUTTON, R. I. The Virtues of Closet Qualitative Research. Organization Science, v. 8, n. 1, p. 97-106, 1997.

TRACY, S. J. Qualitative Quality: Eight “Big-Tent” Criteria for Excellent Qualitative Research. Qualitative Inquiry, v. 16, n. 10, p. 837-851, 2010.

Qualitative Research Methods - collecting evidence, crafting analysis, communicating impact. Oxford: Wiley-Blackwell Publishing, 2013.

TRAINOR, A. A.; GRAUE, E. Evaluating Rigor in Qualitative Methodology and Research Dissemination. Remedial and Special Education, v. 35, n. 5, p. 267-274, 2014. VAN MAANEN, J. Reclaiming Qualitative Methods for Organizational Research: A Preface. Administrative Science Quaterly, v. 24, n. 4, p. 520-526, 1979.

WASSERFALL, R. R. Reflexivity, Feminism and Difference. In: HERTZ, R. (Ed.). Reflexivity \& Voice. London: SAGE Publications, 1997. p.150-167.

WHITTEMORE, R.; CHASE, S. K.; MANDLE, C. L. Validity in Qualitative Research. Qualitative Health Research, v. 11, n. 4, p. 522-537, 2001.

WOLCOTT, H. F. Writing Up Qualitative Research. 2.ed. London: Sage Publications, 2001. 


\section{DADOS DOS AUTORES}

MARIA FERNANDA RIOS CAVALCANTI^ maria.cavalcanti@puc-campinas.edu.br Doutora em Administração de Empresas pela FGV-EAESP

Instituição de vinculação: Pontifícia Universidade Católica - Campinas

Campinas/SP - Brasil

Áreas de interesse em pesquisa: Estudos Organizacionais, Filosofia e Análise Organizacional, Estudos Críticos, Metodologia Qualitativa, Novas Formas Organizacionais e Empreendedorismo Social.

${ }^{\star}$ Rodovia Dom Pedro I, Km 136, s/n-Prédio Administrativo 02, Núcleo de Pesquisa e Extensão do CEA Parque das Universidades Campinas/SP 13086-900 